\title{
Factors associated with death or volume replacement in patients with trauma due to penetrating injuries
}

\author{
Fatores associados ao óbito e à reposição volêmica em pacientes com trauma por lesões \\ penetrantes
}

Márcia Cristine Pires Travassos ${ }^{1}$, Isabel Cristina Bandeira da Silva ${ }^{1}$, João Paulo Bessa de Lima $^{1}$, Celso Martins Fonseca $^{1}$, Jacqueline de Almeida Gonçalves Sachett ${ }^{1}$, Sibila Lilian Osis ${ }^{1}$

Objective: to evaluate the prognostic factors of volume replacement in patients with trauma due to penetrating injuries. Methods: retrospective cohort study whose data were obtained by analyzing medical records of 544 patients who were admitted to the emergency unit, victims of penetrating trauma. Results: among the victims, $282(51.9 \%)$ suffered stab wound, $262(48.2 \%)$ injury by firearms, 486 (89.3\%) were male, 382 (70.2\%) were aged between 14 and 30 years. Most who received volume greater than $2000 \mathrm{ml}$, systolic blood pressure $\leq 90 \mathrm{mmHg}$ and mean arterial pressure $\leq 65 \mathrm{mmHg}$ presented more mortality, with $\mathrm{p}<0.05, \mathrm{p}<0.002$ and $\mathrm{p}$ $<0.003$, respectively. Conclusion: the limited volume replacement can help in the good prognosis of victims of penetrating trauma.

Descriptors: Patient; Prognosis Trauma; Penetrating Injuries.

Objetivo: avaliar os fatores prognósticos da reposição volêmica em pacientes com trauma por lesões penetrantes. Métodos: estudo de coorte retrospectiva cujos dados foram obtidos através da análise de prontuários de 544 pacientes que deram entrada no serviço de emergência, vítimas de traumatismo penetrante. Resultados: dentre as vítimas, 282 (51,9\%) sofreram ferimento por arma branca, 262 (48,2\%) ferimento por arma de fogo, 486 (89,3\%) eram do sexo masculino, com idade entre 14 e 30 anos 382 (70,2\%). A maioria que recebeu fluído maior que $2000 \mathrm{ml}$, pressão arterial sistólica $\leq 90 \mathrm{mmHg}$ e pressão arterial média $\leq 65 \mathrm{mmHg}$, apresentou mais mortalidade, com valor de $p<0,05, p<0,002$ e p $<0,003$, respectivamente. Conclusão: a reposição volêmica limitada pode auxiliar no bom prognóstico do paciente vítima de trauma penetrante.

Descritores: Paciente; Prognóstico Trauma; Traumatismos Penetrantes.

\footnotetext{
${ }^{1}$ Universidade do Estado do Amazonas. Manaus, AM, Brazil.

Corresponding author: Márcia Cristine Pires Travassos

Universidade do Estado do Amazonas. Av. Carvalho Leal, 1610, CEP: 87050-900. Manaus, AM, Brazil. E-mail: travassos89@gmail.com
} 


\section{Introduction}

In recent years, there have been many advances with regard to improving the quality of life in the Brazilian population. However, external causes, especially severe trauma, have become a major cause of death among male individuals aged up to 35 years. This is a consequence of the increasing violence in modern society, which entails high costs related to hospitalization and rehabilitation ${ }^{(1-4)}$.

Trauma caused by penetrating injuries may lead to severe internal bleeding, because especially the trunk lesions, which affect heart, liver, spleen, kidney and large vessels areas, tend to be lethal due to the rapid evolution. The identification of the etiology and prompt treatment are crucial to reduce morbidity and mortality, and the adoption of strategies aimed at improving the management of victims of penetrating trauma are of paramount importance ${ }^{(1,5-6)}$.

Volume replacement has proved to contribute significantly in the probability of survival, since it may be associated with lower occurrence of shock by its function of maintaining hemodynamic balance, tissue oxygenation and by restoring tissue perfusion and functionality of various organs and systems ${ }^{(6-9)}$. The correction of the deficit in intravascular volume aims to improve myocardial performance by increasing end-diastolic volume, optimizing oxygen transport.

In most cases, it is difficult to determine the volume of blood lost and thus, it may be underestimated. The loss from 10.0 to $15.0 \%$ of blood volume is associated with clinical signs which are easily controlled by the body. However, the loss from 20.0 to $35.0 \%$ is associated with the clinical syndrome of hypovolemic shock, whereas loss above or equal to $40.0 \%$ is associated with mortality ${ }^{(9)}$.

The shock is usually established when there is hypoperfusion of vital organs, causing that the body tries to compensate it by activating the sympathetic branch of the autonomic nervous system, causing peripheral vasoconstriction, tachycardia and increased myocardial contractility, triggering increased oxygen demand $(6,10)$.

There are several options of fluids for volume replacement of individuals with multiple traumas, such as crystalloids, protein-colloids and hypertonic solutions. Some guidelines recommend the crystalloid solutions as the first option. However, the solution to be infused in a hemodynamically unstable patient is still the subject of much study and discussion, because they have advantages and disadvantages ${ }^{(2,3,10)}$.

It is understood that the approach to this theme is of great importance, since the violence in Brazil is a serious problem that generates high spending on public health. The choice of this theme for the development of this study emerged from reading on the subject and from understanding the importance of the nursing professional to be aware and prepared to meet victims of penetrating trauma who require volume replacement in health facilities.

This study aims to contribute to the literature and health services, providing the basis for a reflection on the importance of new research that supports the actions of nursing professionals in the care for these patients. In this sense, the following question emerged as research object: what are the prognostic factors of volume replacement in patients with trauma due to penetrating injuries? To clarify this issue, the objective was to evaluate the prognostic factors of volume replacement in patients with trauma due to penetrating injuries.

\section{Methods}

This study is a retrospective cohort study whose data were collected in the records of patients who were admitted in the reference units of the emergency service to trauma victims in the city of Manaus-AM, Brazil.

For the selection of medical records, the following inclusion criteria were observed: medical records of patients with penetrating trauma and age above 14 years. Authors analyzed information from 571 records from January to June 2013, and 27 were 
records excluded from the study because they did not meet the research criteria. For data collection, it was used an instrument developed by the authors, which allowed to obtain sociodemographic and clinical data.

The variables analyzed included: a) patient's gender; b) age; c) diagnosis classified according to the International Classification of Diseases 10; d) origin e) volume replacement; f) length of hospital stay; g) affected system; h) hemodynamic parameters; i) indication of surgical exploration; and j) outcome.

After data collection, the collected information was transferred to a database built in ODK Collect software and then processed in the Excel 2010 software and Epi Info. Descriptive and analytical analyzes (simple frequency distribution, average calculation, standard deviation and significance level-statistical Z test) were carried out and made available on tables, so that it was possible to analyze and compare the information with other research conducted on the subject.

The study complied with the formal requirements contained in the national and international regulatory standards of research involving human beings.

\section{Results}

Of the total of 571 records of patients with penetrating trauma, only 544 met the criteria established by research. Considering the sociodemographic characteristics, 486 (89.3\%) victims were male, aged between 14 and 30 years; 382 (70.2\%) had mean age of $27.8 \pm 10.6$ years, minimum of 14 years old and maximum of 80 years old, with prevalence in young male adults.

Most of the victims came from the capital Manaus, 453 (83.3\%), while the others were distributed among the cities of Amazonas State, which suggests some deficiency in the medium and high complexity care of these regions.

Regarding the main cause of trauma, the penetrating trauma with a higher prevalence in admission process was the stab wound, with 282
(51.8\%) cases, followed by 262 (48.2\%) injuries by firearms. However, when compare the capital and the countryside, separately, Manaus had 226 (86.3\%) cases of injuries by firearms, while the countryside had more cases of stab wound, 41 (14.5\%), compared to injuries by firearms. This data are shown in Table 1.

With respect to the records of procedures performed in pre-hospital care, it is emphasized the large number of records without that information, making it impossible to analyze this variable.

Table 1 - Characterization of victims of penetrating trauma as to the age, gender and origin

\begin{tabular}{lccc}
\hline Variables & $\begin{array}{c}\text { Stab wound } \\
(\mathbf{n = 2 8 2})\end{array}$ & $\begin{array}{c}\text { Injury by } \\
\text { firearm (n=262) }\end{array}$ & $\begin{array}{c}\text { Total } \\
(\mathbf{n = 5 4 4})\end{array}$ \\
\cline { 2 - 4 } & $\mathbf{n ~ ( \% )}$ & $\mathbf{n ~ ( \% )}$ & $\mathbf{n}(\mathbf{\%})$ \\
\hline Age range (in years) & & & \\
14 - 20 & $71(25.2)$ & $84(32.1)$ & $155(28.5)$ \\
21 - 30 & $120(42.6)$ & $107(40.8)$ & $227(41.7)$ \\
31 - 40 & $48(17.0)$ & $44(16.8)$ & $92(16.9)$ \\
41 - 50 & $28(9.9)$ & $16(6.1)$ & $44(8.1)$ \\
51 - 60 & $12(4.3)$ & $8(3.1)$ & $20(3.7)$ \\
$>60$ & $3(1.1)$ & $3(1.2)$ & $6(1.1)$ \\
Gender & & & \\
Male & $249(88.3)$ & $237(90.5)$ & $486(89.3)$ \\
Female & $27(9.6)$ & $23(8.9)$ & $50(9.2)$ \\
Uninformed & $6(2.1)$ & $2(0.8)$ & $8(1.3)$ \\
Origin & & & \\
Countryside & $41(14.5)$ & $13(5.0)$ & $54(9.9)$ \\
Manaus & $227(80.5)$ & $226(86.3)$ & $453(83.3)$ \\
Uninformed & $14(5.0)$ & $23(8.8)$ & $37(6.8)$ \\
\hline Descriptive analysis by simple frequency & &
\end{tabular}

By relating the clinical profile, it was found that according to the hemodynamic assessment at admission, only $30(6.0 \%)$ of the total cases had hemodynamic instability with systolic blood pressure s90mmHg; of these, nine (32.0\%) died when relating to the variable mortality. However, $371(68.0 \%)$ of the total cases presented clinical stability, followed by 143 (26.0\%) of unreported data.

By analyzing the mean arterial pressure, it was 
found that only 338 patients has this data informed, $21(6.2 \%)$ showed mean arterial pressure $\leq 65 \mathrm{mmHg}$, mean ( \pm standard deviation) of $89.8 \pm 16.4 \mathrm{mmHg}$, of these, 5 (23.8\%) died. Of the total of the variable mean arterial pressure, $317(58.3 \%)$ presented $\geq 65 \mathrm{mmHg}$, however, $13(4.1 \%)$ of these died, 19 (6.0\%) did not have the information of outcome. In the analysis of the variable pulse, 19 (3.0\%) were in bradysphygmia (pulse <60bpm), 67 (12.0\%) tachysphygmia (pulse> $100 \mathrm{bpm}$ ), while 290 (53\%) patients were within the normal parameters. Regarding respiratory rate, 73 (13.0\%) were in tachypnea (respiratory rate $>20 \mathrm{irpm}$ ), 142 (26.0\%) were eupneic (respiratory rate from 12 to $20 \mathrm{irpm}), 328$ (60.0\%) did not have information on this variable. Most were hemodynamically unstable.

The mean length of stay was $8 \pm 8.5$ days, with a minimum time of one day and maximum time of 60 days; the length of stay was mostly short, as 250 (46.0\%) cases had the highest proportion from 4 to 10 days, followed by 1 to 4 days in 160 (29.4\%) cases, > 10 days in 111 (20.4\%) cases and 23 cases of uniformed days of hospitalization. Considering the length of stay and mortality, patients who remained hospitalized for longer than 10 days had a higher prevalence of deaths, accounting for 12 (11.5\%) cases compared to those who remained for a shorter period with a prevalence of $27(7.0 \%)$ cases.

As for the targeted treatment, 123 (23.0\%) of the victims were subjected to clinical treatment. However, $393(72.0 \%)$ of cases of penetrating injury required surgical procedure; in 194 (49.0\%) cases the surgery was accomplished mainly within one to six hours after admission. Exploratory laparotomy was the most performed procedure, with 216 (55.0\%) cases, followed by suture, 50 (13.0\%), and vascular exploration, 44 (11.0\%); however, 118 (31.9\%) cases were distributed among other surgical procedures and the percentage may exceed $100.0 \%$ because some patients required to undergo more than one procedure. Regarding admission to the intensive care unit, only 54 patients $(10.0 \%)$ of the total were referred to this sector.
It was observed that the cardiovascular system represented $49(9.0 \%)$ of the affected systems; however, when relating to the trauma mechanism separately, $33(12.0 \%)$ patients with stab wounds knives and $16(6.0 \%)$ patients with injuries by firearms had this system affected. It was found, however, that the musculoskeletal system was the most affected system, with 269 (49.5\%) cases, followed by the respiratory system, with a prevalence of $182(33.5 \%)$ cases.

As the variable procedures performed on hospital admission, 413 (75.9\%) of the victims were subjected to some kind of procedure, and the most common procedures were peripheral venous access, in 348 (64.0\%) patients, followed by closed chest drainage, in 124 (23.0\%) patients, and indwelling catheter, in $86(16.0 \%)$ patients. Of the total, 187 $(17.0 \%)$ patients underwent other procedures and $131(24.0 \%)$ did not have this data informed. However, the final percentage can exceed $100.0 \%$, as there were patients who underwent more than one procedure.

Table 2 - Distribution of victims according to volume replacing solutions

\begin{tabular}{|c|c|c|}
\hline Variables & n (\%) & IC95\%* \\
\hline \multicolumn{3}{|c|}{ Volume replacing solution in multiple trauma } \\
\hline Lactated Ringer's solution & $247(45.4)$ & $41.2-49.5$ \\
\hline Saline solution $(0.9 \%)$ & $139(25.5)$ & 21.8-29.2 \\
\hline Others & $25(4.6)$ & $2.83-6.3$ \\
\hline Hemoconcentrated solution & $16(2.9)$ & $1.52-4.36$ \\
\hline Colloid & $4(0.7)$ & $0.01-1.45$ \\
\hline Total & $544(100.0)$ & - \\
\hline \multicolumn{3}{|c|}{ Volume replacing solution in operating room } \\
\hline Lactated Ringer's solution & $273(69.5)$ & $64.91-74.01$ \\
\hline Saline solution $(0.9 \%)$ & $226(57.5)$ & $52.61-62.39$ \\
\hline Hemoconcentrated solution & $40(10.2)$ & 7.18-13.16 \\
\hline Other & $21(5.3)$ & $3.11-7.56$ \\
\hline Colloid & $6(1.5)$ & $0.31-2.73$ \\
\hline Normal saline solution & $1(0.3)$ & $0.01-0.75$ \\
\hline Total & $393(100.0)$ & - \\
\hline
\end{tabular}


When considering the volume replacement, 544 (100.0\%) of the victims underwent fluid replacement in multiple trauma, and of these, $55(10.1 \%)$ required a second replacement and $3(0.6 \%)$ a third replacement. The infusion of volume on admission ranged from $300 \mathrm{ml}$ to $11.000 \mathrm{ml}$, averaging $1115.6 \pm 1020 \mathrm{ml}$, while the volume infused in the surgical procedure ranged from $500 \mathrm{ml}$ to $10250 \mathrm{ml}$, averaging $2237.5 \pm 1480 \mathrm{ml}$.

The analysis showed that isotonic crystalloid solutions such as lactated Ringer's solution and 0.9\% saline solution were the most frequent, followed by hemoconcentrated solution. For the study, it was considered the volume replacement within the first 24 hours of the initial care.

In general, at admission, 247 (45.4\%) patients received lactated Ringer's solution, followed by saline solution in 139 (25.5\%) cases, while in the operating room, despite the lactated Ringer's solution and the saline solution continued to be the first choice replacing solutions, the hemoconcentrated solution represented 40 (10.2\%) cases. Data are expressed in Table 2.

Table 3 - Clinical characterization of the study population

\begin{tabular}{|c|c|c|c|}
\hline \multirow[t]{2}{*}{ Variables } & \multicolumn{2}{|c|}{$\begin{array}{l}\text { Stab wound Injury by fire- } \\
(n=282) \quad \text { arm }(n=262)\end{array}$} & \multirow{2}{*}{$\begin{array}{c}\begin{array}{c}\text { Death } \\
(n=42)\end{array} \\
n(\%) \\
\end{array}$} \\
\hline & n (\%) & n (\%) & \\
\hline \multicolumn{4}{|l|}{ Treatment } \\
\hline Clinical & $58(47.2)$ & $65(52.9)$ & $2(1.6)$ \\
\hline Surgical & $210(53.4)$ & $183(46.6)$ & $38(9.7)$ \\
\hline Intensive care unit & $22(40.7)$ & $32(59.3)$ & $19(35.2)$ \\
\hline \multicolumn{4}{|c|}{ Total administered volume (ml) } \\
\hline$\leq 2000$ & $164(54.0)$ & $140(46.1)$ & $9(3.0)$ \\
\hline$>2000$ & $118(49.2)$ & $122(50.8)$ & $33(13.8)$ \\
\hline
\end{tabular}

Of the total of victims, 304 (55.9\%) underwent volume replacement up to $2000 \mathrm{ml}$ and 240 (44.12\%) greater than $2000 \mathrm{ml}$, averaging $2501.7 \pm 2061,4 \mathrm{ml}$, minimum volume of $500 \mathrm{ml}$ and a maximum of $16.000 \mathrm{ml}$. Analyzing the $42(7.7 \%)$ deaths, comparing the administered volume with the outcome, it was observed that patients who did volume replacement greater than $2000 \mathrm{ml}$ died, representing 33 (13.8\%) victims.

Mortality related to the infused volume in patients with penetrating trauma, through the analysis by calculating the mean and standard deviation by the Student's t statistical test was significant ( $p<0.01)$, as there were more deaths in patients who received more than $2000 \mathrm{ml}$ (Table 4) in infusion. Of the analyzed records that had information about the volume, 34 $(1.85 \%)$ did not have information on the outcome and 226 (41.54\%) did not have information related to volume replacement performed in the operating room.

Table 4 - Characterization of replacement volume and days of hospital stay according to mortality

\begin{tabular}{|c|c|c|c|}
\hline \multirow{3}{*}{ Variables } & \multicolumn{2}{|c|}{ Death } & \multirow{3}{*}{$\mathbf{p}^{*}$} \\
\hline & Yes & No & \\
\hline & Average $( \pm S D)$ & Average $( \pm S D)$ & \\
\hline \multicolumn{4}{|l|}{ Total volume } \\
\hline In multiple trauma & $1280 \pm 1115.5$ & $1088.5 \pm 982.2$ & 0.228 \\
\hline In the operating room & $3493.8 \pm 2289$ & $2097.7 \pm 1278.3$ & $<0.001$ \\
\hline $\begin{array}{l}\text { Multiplue trauma + } \\
\text { operating room }\end{array}$ & $4191.5 \pm 2812.2$ & $2356.9 \pm 1894.3$ & $<0.001$ \\
\hline Days in hospital & $7.3 \pm 10.6$ & $7.8 \pm 8.2$ & 0.034 \\
\hline
\end{tabular}


Tabela 5 - Distribuição das variáveis clínicas, volume de reposição e repositor segundo a mortalidade

\begin{tabular}{|c|c|c|c|}
\hline \multirow[b]{2}{*}{ Variables } & \multicolumn{2}{|c|}{ Death } & \multirow[b]{2}{*}{$\mathbf{p}^{*}$} \\
\hline & $\begin{array}{c}\text { Yes } \\
\text { n(\%) }\end{array}$ & $\begin{array}{c}\text { No } \\
\text { n(\%) }\end{array}$ & \\
\hline \multicolumn{4}{|c|}{ Systolic blood pressure (mmHg) } \\
\hline$\leq 90$ & $9(32.1)$ & $19(67.9)$ & $<0.001^{*}$ \\
\hline$>90$ & $11(3.2)$ & $338(96.8)$ & \\
\hline \multicolumn{4}{|c|}{ Average blood pressure (mmHg) } \\
\hline$\leq 65$ & $7(26.9)$ & $19(73.1)$ & $<0.001^{*}$ \\
\hline$>65$ & $13(3.7)$ & $338(96.3)$ & \\
\hline \multicolumn{4}{|c|}{ Lenght of stay (days) } \\
\hline$\leq 10$ & $27(6.9)$ & $366(93.1)$ & $0.171^{* *}$ \\
\hline$>10$ & $12(11.5)$ & $92(88.5)$ & \\
\hline \multicolumn{4}{|l|}{ Surgery } \\
\hline Yes & $38(10.3)$ & $331(89,7)$ & $0.005^{* *}$ \\
\hline No & $2(1.7)$ & $115(98,3)$ & \\
\hline \multicolumn{4}{|c|}{ Total volume in multiple trauma (ml) } \\
\hline$\leq 2000$ & $36(7.9)$ & $422(92,1)$ & $0,494^{*}$ \\
\hline$>2000$ & $6(11.5)$ & $46(88,5)$ & \\
\hline \multicolumn{4}{|c|}{ Total volume in the operating room (ml) } \\
\hline$\leq 2000$ & $12(6.1)$ & $184(93.9)$ & $<0.001^{* *}$ \\
\hline$>2000$ & $23(18.9)$ & 99 (81.1) & \\
\hline \multicolumn{4}{|c|}{$\begin{array}{l}\text { Total volume (mutiple trauma + } \\
\text { operating room) (ml) }\end{array}$} \\
\hline$\leq 2000$ & $9(3.2)$ & $274(96.8)$ & $<0.001^{* *}$ \\
\hline$>2000$ & $33(14.5)$ & $194(85.5)$ & \\
\hline \multicolumn{4}{|c|}{ Lactated Ringer's solution } \\
\hline Yes & $4(3.6)$ & $106(96.4)$ & $0.426^{* * *}$ \\
\hline No & $4(6.5)$ & $58(93.5)$ & \\
\hline \multicolumn{4}{|c|}{ Saline solution $0.9 \%$} \\
\hline Yes & $2(3.6)$ & $53(96.4)$ & $0.999 *$ \\
\hline No & $8(4.9)$ & $156(95.1)$ & \\
\hline
\end{tabular}

\section{Discussion}

This study, whose analysis addresses the volume replacement in victims of penetrating trauma, allowed the knowledge of relevant data. In the analysis of socio-demographic data, there was a significant predominance of young male adults of working age among the main victims. That result is similar to studies that have obtained age range equivalent to the second and third decade of life, assuming that this data is related to the fact that males engage more frequently at risk situation $\mathbf{s}^{(4-5,11-12)}$.

By relating the injury mechanism, it was found that the most prevalent penetrating trauma was the stab wound, demonstrating higher prevalence of referral to surgery, perhaps related to increased severity of injury, and exploratory laparotomy was most performed procedure. Penetrating trauma is more severe when compared to closed trauma, thus, surgical intervention is extremely necessary ${ }^{(5,11)}$.

As for specific treatment, 123 (22.6\%) patients received clinical treatment and, of these, two (1.6\%) died, while those received surgical treatment of 393 $(72.2 \%)$ to 38 (9.7\%), had mortality representation, considering stab wounds and injuries by firearms. The surgical procedure is a process aimed at damage control, establishment of integrity and enables better results in severely traumatized patient ${ }^{(13)}$.

As evidenced, patients who received surgical treatment were more often referred to the Intensive Care Unit, with relatively high rates when compared to those who received medical treatment. By linking the length of hospital stay, it was found that victims who remained hospitalized for a shorter period than 10 days showed a favorable clinical outcome ${ }^{(12)}$.

When analyzing the systolic blood pressure and mean arterial pressure of patients undergoing volume replacement during surgery and hospital admission, it was observed that these parameters were mostly normal. However, when relating the total number of victims with hemodynamic instability and the death variable, it was observed that patients who had a mean blood pressure $\leq 65 \mathrm{mmHg}$ and systolic blood pressure $\leq 90 \mathrm{mmHg}$ had a higher prevalence in cases of mortality, since this group had statistically significant difference $\mathrm{p}<0.003$ and $\mathrm{p}<0.002$, respectively, with a higher tendency to worse prognosis ${ }^{(11)}$. Respiratory frequency was altered in $15.0 \%$ of cases, as referred in the literature ${ }^{(14)}$, inferring the body's attempt to compensate for a metabolic acidosis and optimize 
oxygen to the body in the most serious cases, due to blood loss.

The volume replacement with crystalloid was the replacement solution of first choice. However, in the surgical environment, there was relative prevalence of colloids. Nevertheless, it was not possible to show significant differences in the type of replacement solution influencing the favorable prognosis, continuing the discussion between the ideal type of fluid ${ }^{(8,10-11,13,15)}$.

However volume replacement, despite being much discussed, has the function to normalize the systolic blood pressure and improve perfusion, contributed to the survival of the patient. The saline replacing solution tends to significantly influence the worsening of outcomes, but when used in low concentrations of chloride it tends to assist in clinical evolution $^{(13,16)}$. In this context, colloids do not offer benefits to prognosis because of its adverse associated effects $^{(8,13,15)}$.

As found in other literatures ${ }^{(16-17)}$, the results showed that the limited volume replacement may influence patient survival, as well as the hemodynamic balance. However, it is necessary careful evaluation of the type of replacement and the administered volume, since the fluid volume can decrease the blood viscosity, as well as coagulation factors. Similar data were found in a study of traumatized children that states that higher replacement volume was related to higher mortality rate ${ }^{(17-18)}$.

This research agrees with the assumption that in cases where the volume replacement exceeds $2000 \mathrm{ml}$ there is more mortality as the level of statistical significance of the T-Student test infers that there is a relationship between the infused volume and patients' death, considering $\mathrm{p}$ value $<0.05$. Perhaps this is related to the fact that excess liquid would significantly contribute to the difficulty of adjustment of the body, reducing its defense capability, accelerating the hemorrhage before the increase circulating volume and impairing microcirculation and tissue oxygenation, thus requiring more attention of health professionals with the circulatory and cardiovascular systems ${ }^{(6-8,10,16-17)}$.

Considering the results, it is stated the importance of establishing care protocols and criteria in health facilities that generate impact on the management and survival of these patients. The limitations to this study are related to the incomplete filling of records that could allow better exploration of associations with the outcome.

As for limitations, they are related the large number of records lacking information and to the filling essential data for efficient statistical survey, which affected the quality of some information that could help to improve care for the person victim of penetrating trauma. This has been a constant limitation, observed in several studies with similar methodology, mainly related to data in the prehospital care, since it was not possible to analyze these variables.

\section{Conclusion}

The results obtained in this study indicate that limited volume replacement can help in the good prognosis of victims of penetrating trauma, since most patients who have underwent replacement below $2000 \mathrm{ml}$ progressed well. Findings related to the length of stay also showed that survival was higher in patients who had shorter hospital stay.

It was noted during the study that the factors that influenced significantly the unfavorable prognosis were volume replacement higher than $2000 \mathrm{ml}$, length of stay of more than ten days, stab wound, surgical indication, hemodynamic instability related to systolic blood pressure $\leq 90 \mathrm{mmHg}$ and mean arterial pressure $\leq 65 \mathrm{mmHg}$, since these factors had a negative influence on the clinical outcome of patients, resulting in higher mortality in this group. 


\section{Collaborations}

Silva ICB, Lima JPB and Fonseca CM contributed to the collection, organization and interpretation of data. Sachett JAG and Osis SL contributed to writing and relevant critical analysis of the article content. Travassos MCP contributed in the design, data interpretation, article writing and final approval of the version to be published.

\section{References}

1. Souza VS, Santos AC, Pereira LV. Perfil clínicoepidemiológico de vítimas de traumatismo torácico submetidas a tratamento cirúrgico em um hospital de referência. Sci Méd. 2013; 23(2):96101.

2. Wilson JL, Herbella FAM, Takassi GF, Moreno DG, Tineli AC. Lesões fatais em trauma numa grande metrópole brasileira: um estudo de autópsias. Rev Col Bras Cir. 2010; 38(2):122-6.

3. Instituto Brasileiro de Geografia e Estatística. Diretoria de Pesquisas Coordenação de População e Indicadores Sociais Estudos e Pesquisas Informação Demográfica e Socioeconômica. Síntese de indicadores sociais: uma análise das condições de vida da população brasileira. Rio de Janeiro: IBGE; 2010.

4. Reichenhein ME, Souza ER, Moraes CR, Mello JMH, Silva CM, Souza MMC. Violence and injuries in Brazil: the effect, progress made, and challenges ahead. Lancet. 2011; 377(9781):1962-75.

5. Lippi G, Favaloro EJ, Cervellin G. Massive Posttraumatic Bleeding: Epidemiology, Causes, Clinical Features, and Therapeutic Management. Semin Thromb Hemost. 2013; 39(1):83-93.

6. Hussmann B, Heuer M, Lefering R, Touma A, Schoeneberg C, Keitel J, et al. Prehospital Volume Therapy as an Independent Risk Factor after Trauma. Bio Med Res Int. 2015:1-9.
7. Chatrath V, Khetarpal R, Ahuja J. Fluid management in patients with trauma: Restrictive versus liberal approach. J Anaesthesiol Clin Pharmacol. 2015; 31(3):308-16.

8. Delano MJ, Rizoli SB, Rhind SG, Cuschieri J, Junger W,Baker AJ, et al. Prehospital resuscitation of traumatic hemorrhagic shock with hypertonic solutions worsens hypocoagulation and hyperfibrinolysis. Shock. 2015; 44(1):25-31.

9. Tapia NM, Suliburk J, Mattox KL. The initial trauma center fluid management of penetrating injury: a systematic review. Clin Orthop Relat Res. 2013; 471(12):3961-73.

10. Hamada SR, Gauss T, Pann J, Dünser M, Leone M, Duranteau J. European trauma guideline compliance assessment: the ETRAUSS study. Crit Care [Internet]. 2015 [cited 2016 Mar 13]; 19(423):1-8. Available from: http://ccforum. biomedcentral.com/articles/10.1186/s13054015-1092-5

11. Zandomenighi RC, Mouro DL, Martins EAP. Ferimento por arma branca: perfil epidemiológico dos atendimentos em um pronto socorro. Rev Rene. 2011; 12(4):669-77.

12. Naufel Júnior CR, Talini C, Neto LB. Perfil dos pacientes vítimas de trauma torácico atendidos no hospital universitário evangélico de Curitiba (HUEC). Rev Med UFPR. 2014; 1(2):42-6.

13. Chatrath V, Khetarpal R, Ahuja J. Fluid management in patients with trauma: Restrictive versus liberal approach. J Anaesthesiol Clin Pharmacol. 2015; 31(3):308-16.

14. Xiaowu B, Wenkui Y, Wu J, Duan K, Shanjun T, Zhiliang L, et al. Resuscitation strategies with different arterial pressure targets after surgical management of traumatic shock. Crit Care [Internet]. 2015 [cited 2016 Mar 13]; 19(1):1-12. Available from: http://www.ncbi.nlm.nih.gov/ pmc/articles/PMC4411941/pdf/13054_2015_ Article_897.pdf

15. Hammond N, Finfer S. Ressuscitação hídrica no paciente grave: qual opróximo desafio?. Rev Bras Ter Intensiva. 2015; 27(4):309-11. 
16. Duan C, Li T, Liu L. Efficacy of limited fluid resuscitation in patients with hemorrhagic shock: a meta-analysis. Int J Clin Exp Med. 2015; 8(7):64556.

17. Hussmann B, Lefering R, Kauther MD, Ruchholtz $S$, Moldzio $\mathrm{P}$, Lendemans $\mathrm{S}$. Influence of prehospital volume replacement onoutcome in polytraumatized children. Crit Care [Internet]. 2012 [cited 2016 Mar 13]; 16(5):1-8. Available from:http://www.ncbi.nlm.nih.gov/pmc/ articles/PMC3682303/pdf/cc11809.pdf
18. Gourgiotis S, Gemenetzis G, Kocher HM, Aloizos S, Salemis NS, Grammenos S. Permissive hypotension in bleeding trauma patients: helpful or not and when? Crit Care Nurse. 2013; 33(6):18-24. 